\title{
Mineral Profile Evolution of Some Medicinal Plants with Antibacterial Effects
}

\author{
Claudia PAȘCA ${ }^{1}$, Liviu Al. MĂRGHITAȘ ${ }^{1}$, Daniel S. DEZMIREAN ${ }^{1}$, Otilia BOBIȘ ${ }^{1 *}$, Victorița BONTA ${ }^{1}$, Tania \\ C. MIHĂIESCU ${ }^{2}$, Flore CHIRILA $\breve{3}^{3}$ and Nicodim FIȚ ${ }^{3}$
}

${ }^{1}$ Department of Apiculture and Sericiculture. University of Agricultural Sciences and Veterinary

Medicine, Romania.

${ }^{2}$ Department of Environment and Plant Protection. University of Agricultural Sciences and Veterinary

Medicine, Romania.

${ }^{3}$ Department of Microbiology (Veterinary Medicine). University of Agricultural Sciences and Veterinary

Medicine, Romania

* corresponding author: obobis@usamvcluj.ro

Bulletin UASVM Animal Science and Biotechnologies 73(2)/ 2016

Print ISSN 1843-5262; Electronic ISSN 1843-536X

DOI:10.15835/buasvmcn-asb: 12295

\begin{abstract}
Individual minerals and antibacterial activity were investigated in 5 medicinal plants (pot marigold - Calendula officinalis, burdock - Arctium lappa, celandine - Chelidonium majus, basil- Ocimum basilicum, thyme - Thymus vulgaris) using Atomic Absorption Spectroscopy (AAS) technique and antibiogram method. The antibacterial susceptibility has been evaluated over 12 strains isolated from milk microflora, belonging to Staphylococcus, Vibrio, Serratia and Bacillus genera. The obtained results show the best antibacterial effect with Arctium lappa ethanol extracts, having inhibition areas of 6.3 to $17.5 \mathrm{~mm}$, with an average of $9.0 \mathrm{~mm}$ and the highest determined mineral being Calcium.The results obtained open the prospect of using these medicinal plants as an alternative to be used for the control and cure of some mineral deficiencies or for preventing various diseases of the animals.
\end{abstract}

Keywords: alcoholic extracts, feed additives, medicinal plants, strains

\section{INTRODUCTION}

Since long time ago, the demand for natural products with antibacterial activity in fighting of different diseases has been highlighted, especially with the advent of multidrug resistant strains (Chaves et al., 2013).

Therefore, we must explore new ways to improve and protect the health status of farm animals, to guarantee animal performance and to increase nutrient availability (Caspar Wenk, 2003).

Natural feed additives of plant origin, also referred to as phytogenic substances are healthier, less regarded as chemical hazards and generally regarded as safe (Burdock and Carabin, 2004; Hippenstie et al., 2011). Medicinal plants are incorporated in poultry diets to replace synthetic products in order to stimulate or promote the effective use of feed nutrients which may subsequently result in more rapid body weigh gain, higher production rates and improved feed efficiency (Hippenstie et al., 2011).

The medicinal values of some plant species used in the animals feed, it may be due to the presence of $\mathrm{Ca}, \mathrm{Cr}, \mathrm{Cu}, \mathrm{Fe}, \mathrm{Mg}, \mathrm{K}$ and $\mathrm{Zn}$.

Knowledge of the elemental content in medicinal plants are very important, because the environmental factors including atmosphere and pollution, the season of sample collection, the age of plant and soil conditions in which plant grows, physico-chemical properties, including soil type, soil $\mathrm{pH}$ and erosion, affect the concentration of 
elements, as it varies from plant to plant and region to region (Chaves et al., 2013; Maathuis and Diatloff, 2013).

Medicinal plant species belonging to several botanical families, such as Compositae, Lamiaceae, Asteraceae, Papaveraceae were studied.

Efstratiou et al. (2012) reported that pot marigold is approved for food use in U.S.A. and appears in the Food and Drug Administration's list of GRAS (Generally Recognized as Safe) substances.

Calendula officinalis is used as medicinal plant in Europe, China, US and India. It belongs to the Asteraceae family and it is an annual plant with yellow to orange flowers (Muley BP et al., 2009). This plant has a long history of usage as anti-inflammatory, antitumor, antioxidant, antibacterial, anti-HIV, anti-ulcer, antigenotoxic, chemoprotective and antiseptic properties (Rafiee et al., 2015).

Further clinical studies confirm these properties and the ethanol extracts of the $C$. officinalis petals possessed good antimicrobial and antifungal activity comparable with the standard antibiotic, fluconazole (Efstratiou et al. 2012).

Popescu et al. (2010), evaluated the antibacterial activity of a phytotherapeutic agent prepared from an ethyl acetate fraction (AcOEt) extracted from Arctium lappa. This agent inhibited the growth of all tested microorganisms (Pseudomonas aeruginosa, Escherichia coli, Lactobacillus acidophilus, Streptococcus mutans and Candida albicans).

Arctium lappa is a popular vegetable in Japan. It has been used therapeutically in Asia, Europe, and North America for hundreds of years. Burdock contains high amounts of dietary fibers such as inulin and oligosaccharides as well as polyphenols such as chlorogenic and caffeic acid (Okazaki et al., 2013).

Various minerals such as $\mathrm{Na}, \mathrm{K}, \mathrm{Ca}, \mathrm{Mg}, \mathrm{Mn}$, $\mathrm{Fe}, \mathrm{Zn}, \mathrm{Cu}$, were found in burdock roots' powders and extracts, and the mineral contents are bigger in plant powders than in the plant extracts. The data resulted in this analysis can be used in manufacturing of new natural food supplements with hepatoprotective, choleretic and cholagogue properties (Ionescu et al., 2014).

Daniel et al., (2011) found that Ocimum basilicum contain appreciable quantity of $\mathrm{K}, \mathrm{Na}, \mathrm{Ca}$ and $\mathrm{Mg}$ which are essential component of human nutrition and they justified the ethno-medicinal use of the plant. The conclusion were that different solvents may be used in the extraction to provide full data on the components.

Chelidonium majus (Papaveraceae) is a wellknown medicinal herb distributed in Europe, Asia, and Northern Africa and is widely used against various diseases in European countries and Chinese herbal medicines (Monavari et al., 2012; Maji and Banerji, 2015). The extract of $C$. majus was shown to be safe for the use in veterinary and human phyto-preparations (Cho et al., 2006; Maji and Banerji, 2015).

Thymus vulgaris is a perennial medicinal herb in the Lamiaceae family, cultivated worldwide for culinary, cosmetic and medical purposes (Abdulkarimi et al., 2011).

Nowadays, medicinal plants are receiving high attention as feed additives, due to their depressing effects on fat contents of animal products. In this regard, beneficial effects of dietary alfalfa, rosemary, thyme and garlic have been revealed in human and animals (Adler and Holub, 1997; Konjufca et al., 1997; Mottaghitalab and Taraz, 2002; Ponte et al., 2004; Radwan et al., 2008).

Abdulkarimi et al. (2011) found that thyme consumption in broiler chickens could improve the carcass quality, for a higher appreciation by the end users and profitable net returns for the producers.

The aim of the study was to investigate the mineral contents $(\mathrm{Ni}, \mathrm{Na}, \mathrm{Cd}, \mathrm{Cr}, \mathrm{Fe}, \mathrm{Mg}, \mathrm{Ca}, \mathrm{Mn}$, $\mathrm{Pb}, \mathrm{K})$ of some medicinal plants, high antibacterial activity, with benefits for preventing various diseases of the animals, especially for broiler chickens.

\section{MATERIALS AND METHODS Materials}

Marigold and thyme were collected in summer of 2015 from experimental fields of UASVM Cluj. Plants were harvested in the period of their maximum of bioactive principles, dried in the shade and in airy place.

Burdock roots, basil and celandine were purchased from Plafar Cluj. After drying, plant materials were grounded in fine powder and stored in paper bags until extract preparation (Pașca et al., 2016). The bacterial strains used in the experiment derived from both normal microflora, and the pathogenic milk. 12 species were isolated 
belonging to Staphylococcus, Serratia, Vibrio and Bacillus genera.

All reagents used for the analyzes were of analytical purity.

In order to achieve the calibration curve for minerals, dilutions of standard solutions were used: chromium $(10 \mu \mathrm{g} / \mathrm{l})$, manganese $(10 \mu \mathrm{g} / \mathrm{l})$, calcium $(2 \mu \mathrm{g} / \mathrm{l})$, nickel $(50 \mu \mathrm{g} / \mathrm{l})$, iron $(20 \mu \mathrm{g} / \mathrm{l})$, cadmium $(2.0 \mu \mathrm{g} / \mathrm{l})$, sodium $(4.0 \mu \mathrm{g} / \mathrm{l})$, potassium $(5.0 \mu \mathrm{g} / \mathrm{l})$, magnesium $(1.0 \mu \mathrm{g} / \mathrm{l})$, lead $(50 \mu \mathrm{g} / \mathrm{l})$ delivered by Cromatec Plus, Romania (PerkinElmer Instruments, 1991-1999).

\section{Preparation of alcoholic extracts from medicinal plants}

The leaves of celandine, thyme and basil, burdock roots and marigold flowers were evenly dried and ground in a mill. Plant extracts were obtained by maceration for 14 days at room temperature. A solvent extraction with ethanol solution of $5 \%$ concentration in a variable ratio of powders weight: solvent volume was applied. (Ionescu et al., 2014; Pașca et al., 2016).

\section{Determination of antibacterial activity}

To determine the antimicrobial susceptibility of isolates from milk microflora, antibiogram method was used for finding the minimum inhibitory concentration of medicinal plants extracts against microorganisms isolated, using Muller Hilton agar. Bacterial suspension was prepared by inoculating a quantity of bacterial strain grown on an agar plate with sheep blood, in $10 \mathrm{ml}$ of saline until bacterial density coincides to 0.5 McFarland standard. On the Petri plates previously prepared, strains of interest were seeded by flooding technique with bacterial solutions prepared, and after sowing, the excess solution was removed. After the medium surface was dried, 9 microcomprimats with plant extracts were distributed around each plate. Incubation was performed at $37 \pm 2^{0} \mathrm{C}$ for 24 hours and the results were expressed in $\mathrm{mm}$ zone of inhibition (Bobiș et al., 2014; Pașca et al., 2015).

\section{Sample preparation for elemental analysis}

$300 \mathrm{mg}$ of the plant sample was ashed with $2 \mathrm{ml} \mathrm{HNO}_{3}$ acid (65\%) mixture in a Teflon beaker. After homogenization, $3 \mathrm{ml} \mathrm{H}_{2} \mathrm{O}_{2}$ was added.

The mineralization of the samples was carried out in Berghof microwave digestion system MWS2 calciner by following schedule (Tab.1.):

In the end, the solution was transferred in a plastic container graded and the samples are diluted with ultrapure water to a volume of $50 \mathrm{ml}$.

\section{Determination of elements}

Various essential and trace elements such as $\mathrm{Ni}, \mathrm{Cr}, \mathrm{Fe}, \mathrm{Mg}, \mathrm{Ca}, \mathrm{Mn}, \mathrm{Pb}, \mathrm{Na}, \mathrm{Cd}$ and $\mathrm{K}$ in plant samples were analyzed using atomic absorption spectrophotometer (Aanalyst 800, CromatecPlus, U.S.A) equipped with graphite furnace. The inert argon gas flow and the temperature parameters were followed as recommended by manufacturer. The absorption wavelength for the determination of each metal together with its linear working range and correlation coefficient of calibration graphs are given in Table 2. Data were rounded off suitably according to the value of standard

Tab.2.Operating parameters for working elements

Tab. 1. Acid digestion program

\begin{tabular}{cccc}
\hline Steps & 1 & 2 & 3 \\
\hline $\mathrm{T}\left[{ }^{\circ} \mathrm{C}\right]$ & 125 & 165 & 165 \\
\hline Power [\%] & 55 & 70 & 70 \\
\hline Time[min] & 10 & 9 & 1 \\
\hline
\end{tabular}

\begin{tabular}{cccc}
\hline $\begin{array}{c}\text { Elements } \\
\text { Flow }\end{array}$ & $\begin{array}{c}\text { Wavelength } \\
\text { (nm) }\end{array}$ & $\begin{array}{c}\text { Slit } \\
\text { coefficient } \\
\text { (nm) }\end{array}$ & $\begin{array}{c}\text { Width } \\
\text { Correlation } \\
\text { (mA) }\end{array}$ \\
\hline $\mathbf{N i}$ & 232.0 & 0.2 & 0.9999 \\
\hline $\mathbf{C r}$ & 357.9 & 0.7 & 0.9996 \\
\hline $\mathbf{F e}$ & 248.3 & 0.2 & 0.9999 \\
\hline $\mathbf{M g}$ & 285.2 & 0.7 & 0.9988 \\
\hline $\mathbf{M n}$ & 279.5 & 0.2 & 0.9956 \\
\hline $\mathbf{C a}$ & 422.7 & 0.7 & 0.9984 \\
\hline $\mathbf{N a}$ & 589.0 & 0.2 & 0.9990 \\
\hline $\mathbf{C d}$ & 228.8 & 0.7 & 0.9991 \\
\hline $\mathbf{K}$ & 766.5 & 0.7 & 0.9967 \\
\hline $\mathbf{P b}$ & 283.3 & 0.7 & 0.9923 \\
\hline
\end{tabular}


deviation from measurements in triplicate (Subramanian et al., 2012).

\section{Statistical analysis}

Results of the research were analysed for statistical significance by correlation analysis (Ardelean, 2010). This research was performed by three duplicates with a replicate.

\section{RESULTS AND DISCUSSION}

The experimental results obtained in the determination of elements $\mathrm{Ca}, \mathrm{K}, \mathrm{Fe}, \mathrm{Na}, \mathrm{Cd}, \mathrm{Cr}$, $\mathrm{Mg}, \mathrm{Mn}, \mathrm{Ni}$ and $\mathrm{Pb}$ in Calendula officinalis, Arctium lappa, Chelidonium majus, Ocimum basilicum and Thymus vulgaris are shown in Table 3.

The Ca content shows great variations between the different plant species. Ca concentration limits are ranging from $2756.815 \mu \mathrm{g} / \mathrm{kg}$ (Arctium lappa) and $10280.918 \mu \mathrm{g} / \mathrm{kg}$ (Ocimum basilicum). Cr, Mn, $\mathrm{Na}$ were determined in smaller quantities than $\mathrm{Mg}, \mathrm{Cd}, \mathrm{Fe}, \mathrm{K}$ but higher than $\mathrm{Fe}$ and $\mathrm{Pb}$ in other medicinal plants analyzed.

Its concentration limit ranging from 14.476 $\mu \mathrm{g} / \mathrm{kg}$ (Calendula officinalis) and $10280.918 \mu \mathrm{g} / \mathrm{kg}$ (Ocimum basilicum). There were little variations of $\mathrm{Pb}$ content between different species, ranging from $196.514 \mu \mathrm{g} / \mathrm{kg}$ (Ocimum basilicum) and $488.769 \mu \mathrm{g} / \mathrm{kg}$ (Calendula officinalis). Nickel was determined in small concentrations, lower than the first micro-elements analyzed except Arctium lappa and Ocimum basilicum, where the $\mathrm{Ni}$ content registered a value between 1577.045 to 2261.192 $\mu \mathrm{g} / \mathrm{kg}$. The highest value of $\mathrm{Ni}$ content was $2261.192 \mu \mathrm{g} / \mathrm{kg}$ in Arctium lappa and the lowest (685.499 ppm) in Thymus vulgaris. Regarding iron content, Calendula officinalis and Arctium lappa are without iron. The same, for sodium content in Calendula officinalis, Ocimum basilicum and Thymus vulgaris.

As far as the maximum admitted limits of potentially toxic micro-elements $(\mathrm{Cu})$ or very toxic microelements $(\mathrm{Pb})$ is concerned, they are not stipulated in Order no. 975/1998 regarding maximum admitted limits of heavy metals in foods. If we consider herbal teas as foods, maximum admitted concentration limits are $50^{*} 10^{3} \mu \mathrm{g} / \mathrm{kg}$ in $\mathrm{Cu}, 5^{*} 10^{3} \mu \mathrm{g} / \mathrm{kg}$ in $\mathrm{Pb}$ and $0.5^{*} 10^{3} \mu \mathrm{g} / \mathrm{kg}$ in $\mathrm{Cd}$ (ORDIN nr. 975/1998; Gogoasa et al., 2013).

In this case, $\mathrm{Cd}$ concentration in Thymus vulgaris is above maximum admitted limits. The other micro-elements that are slightly toxic $(\mathrm{Pb}, \mathrm{Cd})$ can be found in small amounts in all analysed medicinal plants and are below the apparatus detection potential, which makes them undetectable.

A total of 5 ethanolic extracts from 5 medicinal plants were tested for antibacterial activity against the 12 clinical bacterial species and the une reference bacterial species. The clinical strains used in this work were isolated from mastitis infections diagnosed in a milk cows. Although some extracts exhibited a good antibacterial activity towards different tested bacterial isolates (Figure 1). However, these extracts showed the larger inhibition zone by agar-well diffusion method against the Gram-positive bacteria when compared against the Gram-negative bacteria.

The results of antibacterial activity of pot marigold, burdock, celandine, basil and thyme alcoholic extracts are presented in Figure 1.

The ethanolic extract (96\%) of the medicinal plants showed good activity against Staphilococcus

Tab.3. Micro-elements content average values [ $\mu \mathrm{g} / \mathrm{kg}$ dry weight]

\begin{tabular}{cccccc}
\hline $\begin{array}{c}\text { Micro- } \\
\text { elements }\end{array}$ & $\begin{array}{c}\text { Pot marigold } \\
\text { (Calendula } \\
\text { officinalis) }\end{array}$ & $\begin{array}{c}\text { Burdock } \\
\text { (Arctium lappa) }\end{array}$ & $\begin{array}{c}\text { Celandine } \\
\text { (Chelidonium } \\
\text { majus) }\end{array}$ & $\begin{array}{c}\text { Basil } \\
\text { (Ocimum basilicum) }\end{array}$ & $\begin{array}{c}\text { Thyme } \\
\text { Thymus vulgaris) }\end{array}$ \\
\hline $\mathbf{C a}$ & $3955.907 \pm 7.863$ & $2756.815 \pm 0.960$ & $5605.833 \pm 35.102$ & $10280.918 \pm 58.413$ & $8487.039 \pm 41.542$ \\
\hline $\mathbf{K}$ & $636.106 \pm 10.824$ & $636.303 \pm 0.000$ & $598.167 \pm 3.418$ & $466.007 \pm 19.864$ & $633.433 \pm 3.760$ \\
\hline $\mathbf{F e}$ & - & - & $1037.778 \pm 17.327$ & $91.035 \pm 9.857$ & $1474.465 \pm 14.261$ \\
\hline $\mathbf{N a}$ & - & $275.765 \pm 8.580$ & $340.389 \pm 6.250$ & - & - \\
\hline $\mathbf{C d}$ & $19.412 \pm 2.708$ & $236.868 \pm 9.630$ & $122.222 \pm 7.622$ & $351.840 \pm 10.193$ & $1614.601 \pm 17.295$ \\
\hline $\mathbf{C r}$ & $14.476 \pm 2.871$ & $53.233 \pm 9.109$ & $33.806 \pm \pm 5.560$ & $67.985 \pm 2.482$ & $41.985 \pm 3.214$ \\
\hline $\mathbf{M g}$ & $495.840 \pm 1.022$ & $522.440 \pm 2.259$ & $489.056 \pm 2.275$ & $553.967 \pm 1.716$ & $497.452 \pm 0.315$ \\
\hline $\mathbf{M n}$ & $74.237 \pm 1.754$ & $159.464 \pm 9.953$ & $722.806 \pm 8.014$ & $166.847 \pm 3.115$ & $144.899 \pm 2.414$ \\
\hline $\mathbf{N i}$ & $1296.728 \pm 19.013$ & $2261.192 \pm 37.333$ & $1012.500 \pm 24.022$ & $1577.045 \pm 49.356$ & $685.499 \pm 18.324$ \\
\hline $\mathbf{P b}$ & $488.769 \pm 16.119$ & - & $307.125 \pm 28.579$ & $196.514 \pm 66.409$ & $382.652 \pm 16.450$ \\
\hline
\end{tabular}


inermedius and Bacillus cereus, moderate against Vibrio fluvialis and low activity against Serratia liguefaciens and Staphilococcus xylosus.

The most sensitive Gram-positive bacteria are Staphylococcus intermedius $(11.50 \mathrm{~mm}$, zone of inhibition) and the most resistant Gram negative bacterium is Vibrio fluvialis $(5.40 \mathrm{~mm}$, zone of inhibition). Comparison of antibacterial activity of plants extracts tested on Gram positive and Gram negative bacteria versus negative control (ethanol $96^{\circ}$ ) is reported in the figure 2. (Abdirahman and Batool, 2016; Marasini et al., 2015)

Arctium lappa alcoholic extract analyzed on microflora milk shows the highest efficiency, with an average of $9.00 \mathrm{~mm}$ zone of inhibition, while the alcoholic extract of Ocimum basilicum, have the weakest efficiency to these microorganisms, with an average of $6.30 \mathrm{~mm}$ inhibition zone.
Using correlation analysis (Ardelean, 2010), it was shown that the minerals values and inhibition zone for antibacterial activity is statistically significant for the value of correlation coefficient $\mathrm{r}=0,86$ and transgression probability $\mathrm{P}=5 \%(0,86$ $<0,95$ ).

The results indicate a high content in: $\mathrm{Ca}$ (5605,83 $\mu \mathrm{g} / \mathrm{kg}), \mathrm{Ni}(1012,50 \mu \mathrm{g} / \mathrm{kg}), \mathrm{Fe}(1037,78$ $\mu \mathrm{g} / \mathrm{kg}$ ) and respectively, a significant sensitivity for Chelidonium majus (8.70 mm zone of inhibition), Ca $(8487,04 \mu \mathrm{g} / \mathrm{kg}), \mathrm{Fe}(1474,47 \mu \mathrm{g} / \mathrm{kg}), \mathrm{Cd}(1614,60$ $\mu \mathrm{g} / \mathrm{kg})$, for Thymus vulgaris $(8.20 \mathrm{~mm}$ zone of inhibition), Ca $(3955,91 \mu \mathrm{g} / \mathrm{kg}), \mathrm{Ni}(1296,73 \mu \mathrm{g} /$ $\mathrm{kg}), \mathrm{K}(636,11 \mu \mathrm{g} / \mathrm{kg})$ for Calendula officinalis $(7.00$ $\mathrm{mm}$ zone of inhibition), Ca (10280,92 $\mu \mathrm{g} / \mathrm{kg}), \mathrm{Mg}$ $(553,97 \mu \mathrm{g} / \mathrm{kg}), \mathrm{Ni}(1577,04) \mu \mathrm{g} / \mathrm{kg})$, for Ocimum basilicum (6.30 $\mathrm{mm}$ zone of inhibition) and $\mathrm{Ca}$ $(2756,82 \mu \mathrm{g} / \mathrm{kg}), \mathrm{Ni}(2261,19 \mu \mathrm{g} / \mathrm{kg}), \mathrm{K}(636,3 \mu \mathrm{g} /$ $\mathrm{kg}$ ) for Arctium lappa (9 mm zone of inhibition).

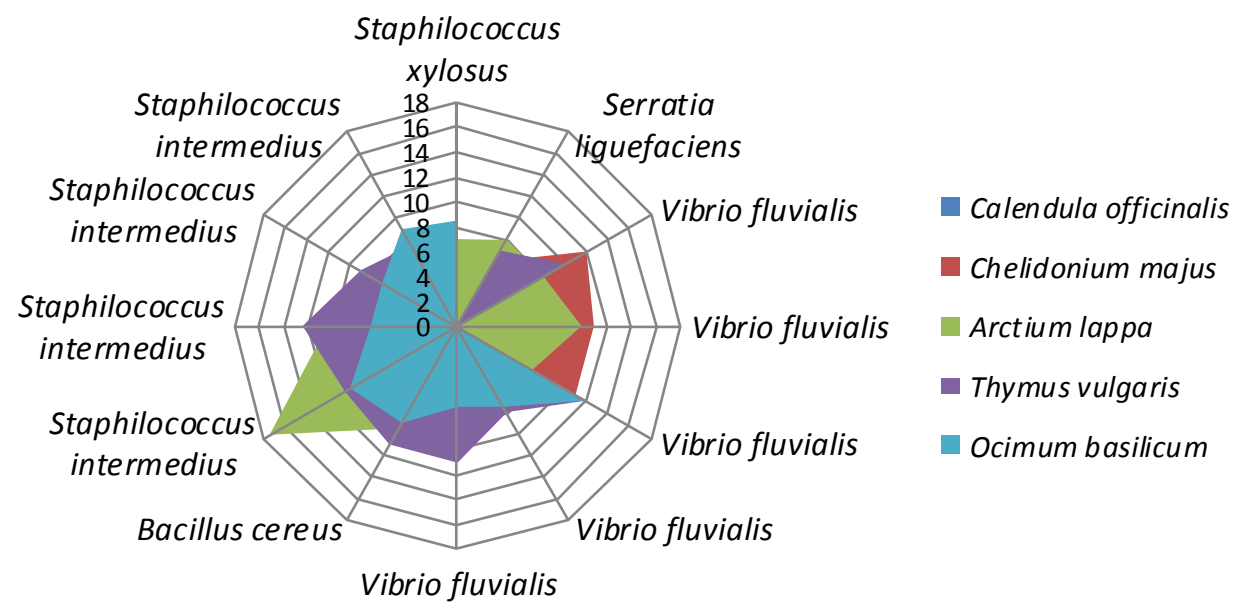

Fig 1. Results of the antibiogram method for the determination of the susceptibility of medicinal plant extracts ( $\mathrm{mm}$, zone of inhibition)

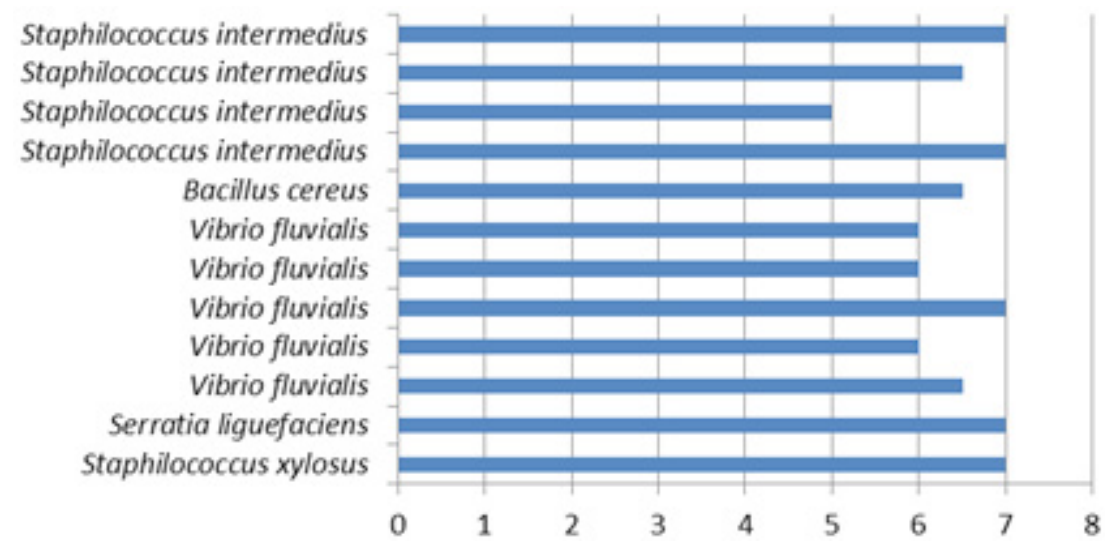

Fig. 2. Results of the antibiogram method for the negative control (mm, zone of inhibition) 


\section{CONCLUSION}

In the concept of the production of healthy farm animals without the use of antibiotics medicinal plants can be relevant in many different ways. They can regulate feed intake and stimulate digestive secretions. An optimized digestion capacity and reduced risk of digestive disorders are the consequence (Caspar W, 2003).

The data obtained in the present work showed that these medicinal plants, specifically, Arctium lappa and Chelidonium majus can be used for the control and cure of some mineral deficiencies or for preventing of various diseases of the animals.

Each of this studied medicinal plants can contribute with their mineral contents to a balanced microflora, an optimal precondition for an effective protection against pathogenic microorganisms and an intact immune system.

\section{Acknowledgments}

Financial support was granted by the project Partnerships in Priority Areas Programme - PN II, developed with the support of MEN - UEFISCDI, project no. $148 / 2014$. The authors declare no conflict of interests.

\section{REFERENCES}

1. Abdirahman A, Batool R (2016). Evaluation of Bioactivity and Preliminary Phytochemical Investigation of Herbal Plants Against Ampicillin Resistant Bacteria, Journal of Basic \& Applied Sciences, 12, 109-117.

2. Adler AJ, Holub BJ (1997). Effect of garlic and fishoil supplementation on serum lipid and lipoprotein concentrations in hypercholesterolemic men. Am. J. Clin. Nutr. 65:445-450.

3. Amal KM, Pratim B (2015). Chelidonium majus L. (Greater celandine) - A Review on its Phytochemical and Therapeutic Perspectives, International Journal of Herbal Medicine. 3 liver, lowers blood cholesterol, proportional liver and abdominal fat weights in broiler chickens. Italian Journal of Animal Science.10: 20.

4. Ardelean M (2010). Principii ale metodologiei cercetării agronomice și medical veterinare. AcademicPres, ClujNapoca, 59-60,152.

5. Bishnu PM, Pankaj B, Pratibha A, Kashi RG, Sanjiv N, Nabaraj D, Anjana S, Laxman G, Kanti S (2015). Evaluation of Antibacterial Activity of Some Traditionally Used Medicinal Plants against Human Pathogenic Bacteria, Hindawi Publishing Corporation BioMed Research International. Article ID 265425, 6 pages. http://dx.doi. org/10.1155/2015/265425

6. Bobis 0, Dezmirean DS, Tomos L, Chirila F, Marghitas LA (2014), Influence of Phytochemical Profile on Antibacterial Activity of Different Medicinal Plants Against
Gram-Positive and Gram-Negative Bacteria. Biochemistry and Microbiology. 51(1): 113- 118.

7. Burdock GA, Carabin IG (2004). Generally regarded as safe (GRAS): history and description. Toxicol Lett. 150:3-18.

8. Caspar W (2003). Herbs and Botanicals as Feed Additives in Monogastric Animals, Asian-Aust. J. Anim. Sci. 16(2) : 282-289.

9. Chaves TP, Santana CP, Veras G, Brandao DO, Felismino DC, Medeiros ACD, Trovao DM. (2013).Seasonal variation in the production of secondary metabolites and antimicrobial activity of two plant species used in Brazilian traditional medicine. Afr. J. Biotechnol. 12(8) : 847-853.

10. Cho KM, Yoo ID, Kim WG (2006). 8-hydroxydihydrochelerythrine and 8-hydroxydihydrosanguinarine with a potent acetylcholinesterase inhibitory activity from Chelidonium majus L. Biological and Pharmaceutical Bulletin; 29(11):2317-2320.

11. Daniel VN, Daniang IE, Nimyel ND (2011). Phytochemical analysis and mineral elements composition of Ocimum Basilicum obtained in jos metropolis, plateau state, Nigeria. International Journal of Engineering \& Technology IJETIJENS 11(06).

12. Efstratios E, Abdullah IH, Poonam S N, John EM, Muhammad AA, Juluri RR (2012). Antimicrobial activity of Calendula officinalis petal extracts against fungi, as well as Gram-negative and Gram-positive clinical pathogens. Complementary Therapies in Clinical Practice 18:173176.

13. Ghazalah AA, ALI AM (2008). Rosemary leaves as a dietary supplement for growth in broiler chickens. Int Poult Sci. 7:234-239.

14. Gogoasa I, Jurca V, Alda LM, Velciov A, Rada M, Alda S, Sirbulescu C, Bordean DM, Gergen I (2013). Mineral Content of Some Medicinal Herbs, Journal of Horticulture, Forestry and Biotechnology. 17(4):65- 67.

15. Hippenstie F, Abdel-Wareth AAA, Kehraus S, Südekum KH (2011). Effects of selected herbs and essential oils, and their active components on feed intake and performance of broilers - a review, Arch.Geflügelk. 75 (4):226-234.

16. Ionescu D, Popescu M, Rizea GD, Mihele D, Bulearca G, Ivopol M, Mihalcea F, (2014). Polyphenols and Minerals, Antioxidants in the Plants Used in the Natural Treatment of Hepatobiliary Disorder, REV. CHIM. (Bucharest). 65(5).

17. Konjufca VH, Pesti GM, Bakalli RI, (1997). Modulation of cholesterol levels in broiler meat by dietary garlic and copper. Poultry Sci. 76:1264-1271.

18. Maathuis FJM, Diatloff E (2013). Roles and functions of plant mineral nutrients. In: Plant Mineral Nutrients: Methods and Protocols, Methods in Molecular Biology, Springer Science 953:1-21.

19. Monavari SH, Shahrabadi MS, Keyvani H, Bokharaei Salim F (2012). Evaluation of in vitro antiviral activity of helidonium majus $L$. against herpes simplex virus type- 1 . African Journal of Microbiology Research; 6(20):43604364.

20. Mottaghitalab M, Taraz Z (2002). Effects of Garlic (Allium Sativum) on egg yolk and blood serum cholesterol in Arya breed laying hens. Brit. Poultry Sci. 43:42-43. 
21. Muley BP, Khadabadi SS, Banarase NB (2009). Phytochemical Constituents and Pharmacological Activities of Calendula officinalis Linn (Asteraceae): A Review, Tropical Journal of Pharmaceutical Research. 8 (5): 455-465

22. Okazaki Y, Sitanggang NV, Sato S, Ohnishi N, Inoue J, Iguchi T, Watanabe T, Tomotake H, Harada K, and Kato N (2013). Burdock Fermented by Aspergillus awamori Elevates Cecal Bifidobacterium, and Reduces Fecal Deoxycholic Acid and Adipose Tissue Weight in Rats Fed a High-Fat Diet, Biosci. Biotechnol. Biochem., 77 (1): 53-57.

23. ORDIN nr. 975/1998 privind limitele maxime de arsen şi metale grele în alimente.

24. Paşca C, Mărghitaş LA, Bobiş O, Dezmirean DS, Mărgăoan R, Mureşan C (2016). Total Content of Polyphenols and Antioxidant Activity of Different Melliferous Plants, Bulletin UASVM Animal Science and Biotechnologies 73(1).

25. Pașca C, Mărghitaș LA, Dezmirean D, Bobiș O, Bonta V, Mărgăoan R, Chirilă F, Fit N (2015). The assessment of the antibacterial activity of some plant extracts on normal and pathogenic microflora from milk. Scientific Papers: Animal Science and Biotechnologies, 48 (1).
26. PerkinElmer Instruments LLC, (1991-1999). The THGA Graphite Furnace, Germany.

27. Ponte PI, Mendes I, Quaresma M, Aguiar MN, Lemos JP, Ferreira LM, Soares MA, Alfaia CM, Prates JA, Fontes CM (2004). Cholesterol levels and sensory characteristics of meat from broiler consuming moderate to high levels of alfalfa. Poultry Sci. 83:810-814.

28. Popescu ML, Dinu M et al. (2010). Contributions to the pharmacognostical and phytobiological study on Taraxacum officinale (L.) Weber. In: Farmacia, 58(5): 646653.

29. Radwan NL, Hassan RA, Qota EM, Fayek HM (2008). Effect of natural antioxidant on oxidative stability of eggs and prodactive and reproductive performance of laying hens. Int. J. Poultry Sci. 7:134-150.

30. Rafiee H, Mehrafarin A, Labbafi M, Qaderi A, Naghdi Badi $\mathrm{H}$ (2015). Mineral elements and biochemical analysis of Calendula officinalis l. Affected by bio-stimulators. Trakia Journal of Sciences. 1:27-35.

31. Subramanian R, Subbramaniyan P, Raj V (2012). Determination of some minerals and trace elements in two tropical medicinal plants. Asian Pacific Journal of Tropical Biomedicine S555-S558. 